Sains Malaysiana 50(4)(2021): 919-928

http://doi.org/10.17576/jsm-2021-5003-04

\title{
Rare Earth Elements and Fractionation Of Zr-Hf and Y-Ho: Implication to Petrogenesis of Idanre Granite, Nigeria
}

(Unsur Langka Bumi dan Pecahan Zr-Hf dan Y-Ho: Implikasi terhadap Petrogenesis Granit Idanre, Nigeria)

\author{
Akinola O. OlagoKe*, Azman A. Ghani \& Elvaene James
}

\begin{abstract}
Idanre area which is situated within the Nigerian shield is affected by orogenic activities accompanied by emplacement of Pan-African granitoids. This paper presents a new information on geochemical behaviour of Rare Earth Elements (REEs) and High Field Strength Elements (HFSEs) Zr-Hf and Y-Ho that can explain post magmatic processes relating to the origin and evolution of the Idanre granite. $\mathrm{Zr}-\mathrm{Hf}, \mathrm{Hf}-(\mathrm{Zr} / \mathrm{Hf})$ and $\mathrm{Y}-\mathrm{Ho},(\mathrm{Y} / \mathrm{Ho})$-Ho variation diagrams depicted similar mobility and migration patterns for Zr, Hf, Y and Ho. Binary plots of Log Zr/Hf vs Log Hf, Log Y/Ho vs Log Ho; high LREE/HREE and negative Eu anomaly shows extensive plagioclase and calcic amphibole fractionation. High $\mathrm{Ce} / \mathrm{Yb}$ values 113.49, 134.97, and 123.6 reflects low partial melting in the source rocks. Similar Zr/Hf ratios 39.16; 39.3 and 43.26 for members of the granite suite suggest a common source for the minimally differentiated magmatic fluid. Y/ Ho ratios of 27.15, 27.12 and 25.91 indicate that the rock units are comagmatic. Mean $\mathrm{Zr} / \mathrm{Hf}$ (41.69) and Y/Ho (27.18) ratios indicate the host migmatite may be the source rock for the Idanre granite complex.
\end{abstract}

Keywords: Comagmatic; Idanre granite complex; Pan-African granitoids; REEs; $\mathrm{Zr} / \mathrm{Hf}$

\section{ABSTRAK}

Kawasan Idanre yang terletak di dalam kawasan lindungan Nigeria dipengaruhi oleh aktiviti orogenik yang disertai oleh perletakan granitoid Pan-Africa. Kajian ini menyampaikan maklumat baru berkaitan dengan sifat Unsur-unsur Nadir Bumi (REE) dan Unsur Medan Kekuatan Tinggi (HFSE) Zr-Hf dan Y-Ho yang boleh menjelaskan proses selepas magma berkaitan dengan asalan dan evolusi granit Idanre. Rajah variasi $\mathrm{Zr}$-Hf, $\mathrm{Hf}$-(Zr/Hf) dan Y-Ho, (Y/Ho)-Ho menunjukkan mobiliti dan corak penghijrahan yang sama untuk Zr, Hf, Y dan Ho. Plot perduaan Log Zr/Hf lawan Log Hf, Log Y/ Ho lawan Log Ho; LREE/HREE tinggi dan Eu anomali negatif menunjukkan fraksinasi plagioklas dan amfibol kalsik yang luas. Nilai Ce/Yb yang tinggi iaitu 113.49, 134.97 dan 123.6 menunjukkan leburan separa yang rendah dalam batuan punca. Nisbah Zr/Hf menunjukkan nilai 39.16; 39.3 dan 43.26 untuk ahli-ahli suit granit turut mencadangkan pembezaan cecair magma yang kecil untuk punca yang sama. Nisbah Y/Ho iaitu 27.15, 27.12 dan 25.91 menunjukkan unit-unit batuan ialah batuan semagma. Purata nisbah $\mathrm{Zr} / \mathrm{Hf}$ (41.69) dan Y/Ho (27.18) menunjukkan migmatit mungkin boleh menjadi batuan punca untuk kompleks granit Idanre.

Kata kunci: Granitoid Pan-Africa; kompleks granit Idanre; REE, semagma; Zr/Hf

\section{INTRODUCTION}

The evolutionary pathways for Pan-African granitoids in Nigeria have been a subject of much debate. The controversy surrounding the origin of these rocks is tied to the interpretation of their mode of emplacement which is further complicated by varied nature of their chemistry as well as the spatial and geotectonic features of the rocks (Odeyemi 1990). Geochemical and isotopic studies show that these granite suites have either I- type or mixed Iand S- type characteristics (Ajibade et al. 1987). In the light of these uncertainties, Rare Earth Elements (REE) geochemical investigation was carried out to shed more light on the origin of granitoid rocks located in Idanre area of Southwestern Nigeria. The significant growth of interest in geochemistry of REE come from the viewpoint that the observed degree of REE fractionation in rocks of granitic composition can reflect its origin. The abundances of these elements when applied to petrogenetic problems has revolutionalized modern ideas about igneous processes like magma fractionation, hybridization or anatexis of crustal 
protoliths or mantle derivatives (Clark 1984). Variation in REE distribution in granitic rock results from effects of variable temperature, pressure and composition, and REEs are dispersed as minor or trace constituents in accessory mineral phases which are not essential components of rocks. While some accessory minerals favor the LREE (e.g. allanite), others the HREE (e.g. zircon) and Eu anomalies can be generated by fractional crystallization or fusion of plagioclase feldspar, garnet, apatite, allanite, magnetite and possibly clinopyroxene and amphibole (Clark 1984). Zircon tend to be abundance in felsic plutonic rocks (Bea et al. 1996; Gromet \& Silver 1983; Hashino et al. 2006; Umor et al. 2019). Mineral/melt distribution coefficients for REE tend to be higher in silica-rich systems than in basic ones, implying that increasing silica content of a magma will tend to increase mineral/melt REE distribution pattern (Clark 1984). As a ubiquitous minor mineral in igneous series, particularly granites, the presence of zircon in magmas could produce profound effects on the abundance and distribution of trace elements (Bea et al. 1996; Ghani et al. 2019; Gromet \& Silver 1983; Hoshino et al. 2006). Zirconium and hafnium geochemistry may largely depend on the role of zircon to produce considerable effect on migration and distribution of REEs (Nagasawa 1970). In this contribution, prominence is given to REEs abundances and behavior of zirconium-hafnium (Zr-Hf) and yttrium-holmium (Y-Ho).

\section{MATERIALS AND METHOD}

\section{GEOLOGICAL SETTING REGIONAL GEOLOGY}

On a regional geological scale, Nigeria occupies the eastern side of West African craton, south of the Tuareg shield and northwest of the Congo craton (Ferré et al. 1996). The basement complex of southwestern Nigeria (Figure 1) which form the broader view of the study area largely compose of migmatite-gneisses, schistose assemblages that occur in distinct belts, and granitoids. The first unit is oldest and most extensive member of the Nigeria basement (Rahaman 1988) and have been dated to be Archaean- Paleoproterozoic in age (Ekwueme \& Kröner 1992). The schist belts are low-grade metamorphic rocks dominantly composed of pelites to semi pelitic rocks with intercalated metasedimentary assemblages and metavolcanics (Dada 2008). During Neoproterozoic, syncollisional granitoids popularly known as Older Granites intruded into the older lithologic units (Goodenough et al. 2014). The bodies represent unequivocal evidence of granitic additions attributable to orogenic activities (Rahaman 1988). These masses form deep-sited magmatic intrusions that are common throughout the basement complex. The Older Granites range in composition from granites to granodiorites with subordinate gabbros, diorite and quartz syenites (Ogunleye et al. 2005). However, the coarse to porphyritic biotite-granite and biotite-hornblende granite are ubiquitous among other basement rocks. Based on age, structure, mineralogy, chemistry and origin, the Older Granites are quite distinct and easily disinguished from the Younger granites, which are mainly anorogenic high-level magmatic intrusions which has been linked to couldron subsidence and piston faults. The Younger granites are restricted in occurrence to the Mesozoic Tin Province of the Jos Plateau, North central Nigeria.

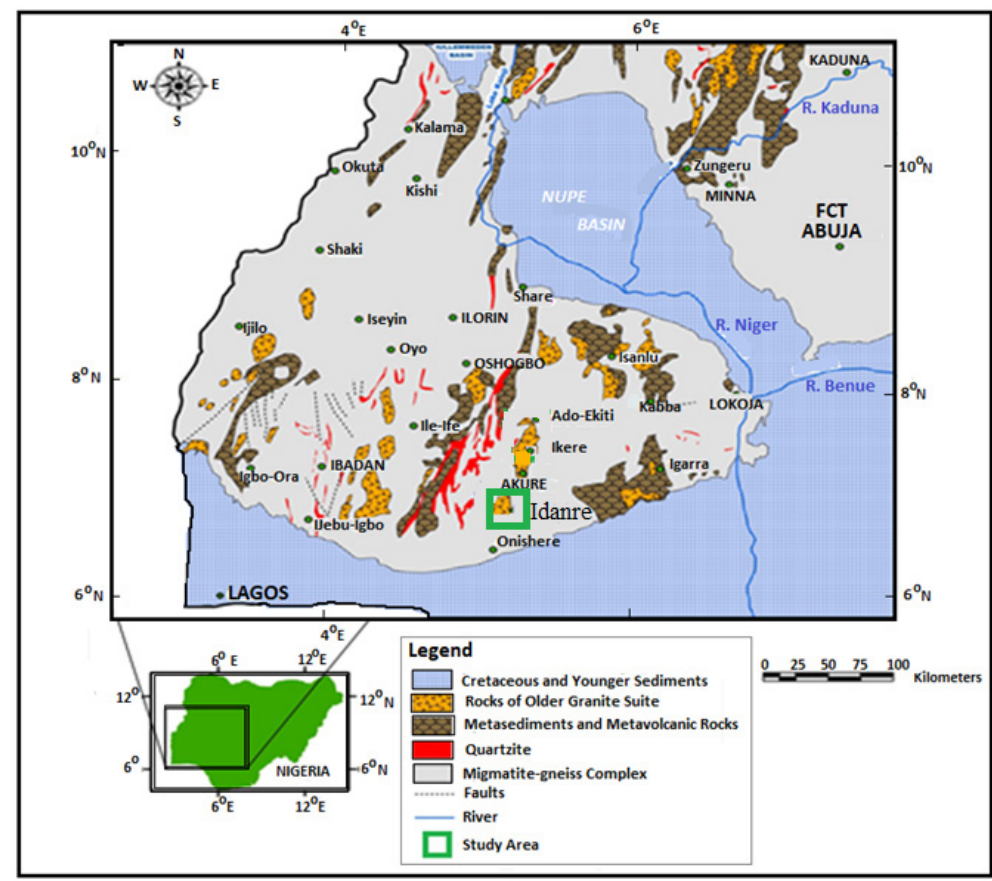

FIGURE 1. Geological map of southwestern Nigeria showing location of Idanre 


\section{LOCAL GEOLOGY}

Idanre area is underlain by migmatite, charnockite and granitoids. The granite which is popularly referred to as Idanre batholith or Idanre granite complex is $550 \pm 100$ Ma in age (Tobosun 1981), emplaced discordantly to semi-concordantly within the migmatite-gneiss basement (Anifowose \& Kolawole 2011). The magnificient granite masses occur within Idanre town and spread into the neighbouring villages in all directions. The granitoid occur in three textural varieties, they are: the coarsegrained undiffrerntiated granite $(\mathrm{OGu})$, the porphyritic granite (OGp), and the fine-grained granite (OGf) (Figure 2 ). Coarse-grained undifferentiated granite forms most of the granite plutons that are located between Alade and Idanre towns and are characterized by extensive outcrops with average elevations ranging between 25-100 m. The Porphyritic granite is more extensive constituting substantial part of the complex, they are represented by massive outcrops and are well-distributed around the built up areas of Idanre town as towering inselbergs. The porphyritic granite is distinguished by its large greyish to pinkish feldspar phenocrysts which sometimes measure up to $5 \mathrm{~cm}$ in length and $3 \mathrm{~cm}$ in width. The fine-grained granite form smaller plutons that occur in the northwestern part of Idanre town.

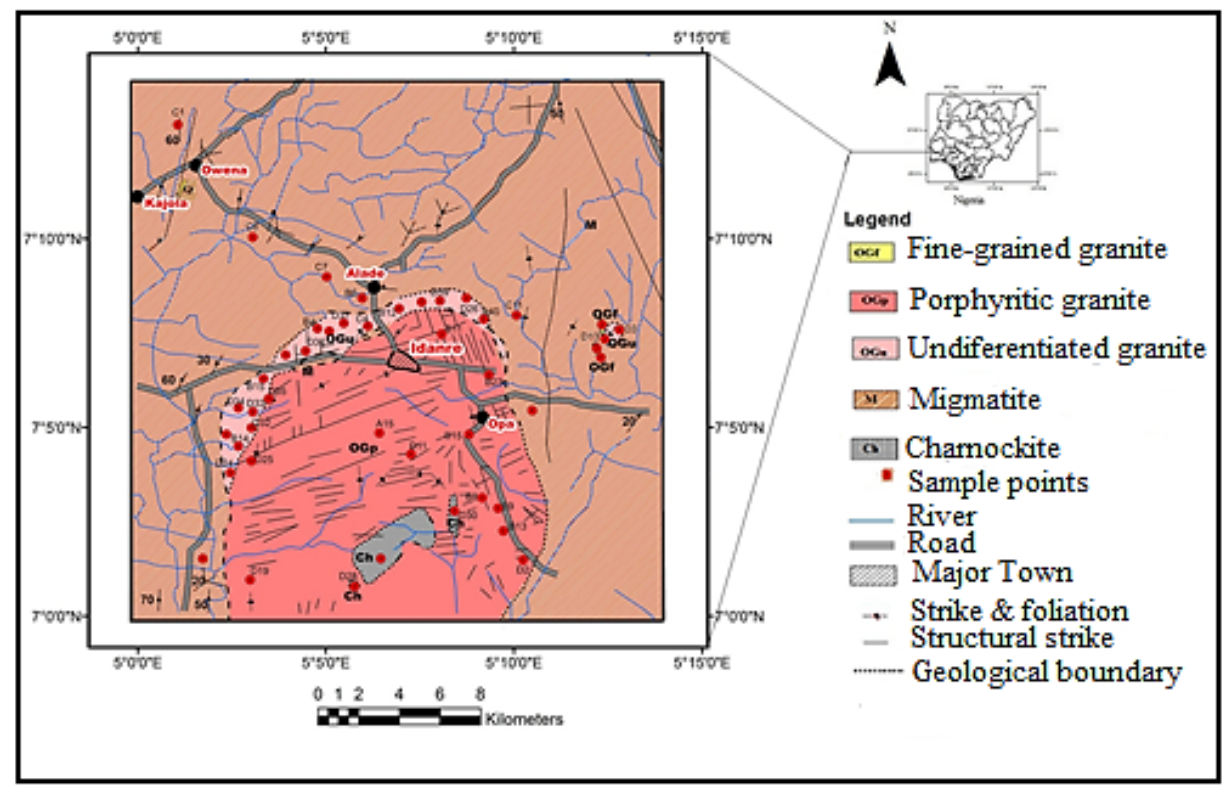

FIGURE 2. Geological map of Idanre area showing the sampling locations

\section{Materials AND MEthods}

Systematic geological mapping was carried out by making traverses across the rocky terrain and walking along bush paths and river channels with the help of a GPS (Map 76 CSX). Following a careful assessment of rocks in the field, structural data are obtained using the Silvatype compass clinometer. Thirty-two (32) representative samples of granite each weighing between 2.5 and $4 \mathrm{~kg}$ are obtained from outcrop exposures of the granitoids using standard geological techniques. Five (5) migmatite gneiss samples representing the country rock are also taken. Three (3) samples are obtained from charnockite which represents associated minor lithology occurring at the core of the granite intrusion. All the samples are subjected to analytical procedures, REE composition was determined on Inductively Coupled Plasma-Mass Spectrometer (ICP-MS) at the Bureau Veritas Vancouver, Canada. For detailed description of trace elements procedures was documented by James et al. (2019). The points where the 
samples are obtained is shown in Figure 2. Major elements composition along with part of the trace element data was previously adopted to constraint the chemical classification and tectonic setting of the granite by the authors. Since this paper focuses on REEs geochemistry, only those trace components that are of petrogenetic significance are presented here with the REE.

\section{RESULTS}

\section{REE GEOCHEMISTRY OF IDANRE GRANITE}

Analytical results of $\mathrm{Hf}, \mathrm{Zr}$, Ho, and Y composition (Table 1) and fourteen Rare Earth Elements (La-Lu) (Table 2) shows the REE fractionation patterns in the granites produced characteristic enrichment of LREE (La, Sm) and HREE (Eu-Lu) patterns with consistent similarities for all the granites (Figures 3 and 4). Table 2 shows that there is a consistent increasing trend in La contents in the granitic rocks. Mean value of $\mathrm{La}$ in the rocks are: OGu (118.46) ppm, OGp (150.88) ppm, and OGf(215.3) ppm. In the same order, similar trends are also observed for Ce (217.46, 277.2, and 395.7) ppm; $\operatorname{Pr}(21.52,27.5$, and 54.8) ppm; $\mathrm{Nd}(70.96,91.08$, and 126.9) ppm; and Sm (10.31, 12.94, and 18.06) ppm, respectively. However, these values are sufficiently higher than the abundances of $25,46,4.6$, and $18 \mathrm{ppm}$ for $\mathrm{Ce}, \mathrm{Pr}, \mathrm{Nd}$ and $\mathrm{Sm}$, respectively, for an average granite (Taylor 1962) (Table 3). The higher values of these elements may be related to the level of fractionation of plagioclase feldspar (Clark 1984). The general REE result indicated that both the migmatite and granitic series show pronounced enrichment in LREE as against HREE. Migmatite gneiss contains higher mean value of LREE (418.23 ppm) and low mean value of HREE (35.78 ppm). However, for granitoids, LREE and HREE values recorded are OGu $(438.71,22.25)$ ppm; OGp $(559.6,25.4) \mathrm{ppm}$; and $\operatorname{OGf}(810.8,34.69) \mathrm{ppm}$, respectively. Again, average LREE/HREE ratios in Migmatite (11.69 ppm); coarsegrained granite (19.72 ppm); Porphyritic granite (22.03 ppm) and Fine-grained granite $(23.37 \mathrm{ppm})$ increase in the same order. The dominance of LREE over HREE may be attributed to fractionation of mainly allanite which favour LREE rather than zircon which favour HREE. LREE has smaller atomic sizes when compared with HREE, so the higher proportion of LREE against HREE in all the rocks may be attributed to preference for incorporation of smaller-sized atoms into the coordination sites of crystal lattices of the rock forming minerals (Jamali 2017). Similarities in REE distribution pattern of both gneissic host and intrusive units may connote direct link with their petrogenetic affinities. The coherent relationship between the abundances of these elements and the seemingly related behaviour of LREE and HREE and their ratios indicated that the granite may have been sourced from partial melting of the migmatite basement (Dalpé \& Baker 2000). This fact may corroborate ideas established from previous work of the authors that the granites are I-type, derived from igneous antecedents.

TABLE 1. REE Hf, Zr, Ho, and Y composition and ratios in rocks from Idanre area

\begin{tabular}{lcrccccc}
\hline ID & Rock & \multicolumn{1}{c}{ Hf } & Zr & Zr/Hf & Ho & Y & Y/Ho \\
\hline B6 & M & 5.20 & 182.20 & 35.04 & 1.09 & 31.70 & 29.08 \\
C1 & $\mathrm{M}$ & 36.10 & 1754.50 & 48.60 & 1.88 & 48.60 & 25.85 \\
C5 & $\mathrm{M}$ & 14.70 & 616.50 & 41.94 & 1.92 & 49.50 & 25.78 \\
C7 & $\mathrm{M}$ & 6.20 & 217.70 & 35.11 & 1.27 & 35.00 & 27.56 \\
C11 & $\mathrm{M}$ & 42.40 & 2025.80 & 47.78 & 1.82 & 50.30 & 27.64 \\
Average & & $\mathbf{2 0 . 9 0}$ & $\mathbf{9 5 9 . 3 0}$ & $\mathbf{4 1 . 6 9}$ & $\mathbf{1 . 6 0}$ & $\mathbf{4 3 . 0 0}$ & $\mathbf{2 7 . 1 8}$ \\
& & & & & & & \\
A1 & OGu & 14.30 & 615.10 & 43.01 & 1.39 & 35.50 & 25.54 \\
B12 & OGu & 50.00 & 187.70 & 37.54 & 0.85 & 22.60 & 26.589 \\
B14 & OGu & 4.40 & 171.30 & 38.93 & 0.64 & 17.20 & 26.88 \\
B15 & OGu & 4.20 & 150.30 & 35.79 & 0.72 & 21.10 & 29.31 \\
C4 & OGu & 8.20 & 332.40 & 40.54 & 0.98 & 29.10 & 29.69 \\
D3 & OGu & 10.20 & 389.70 & 38.21 & 0.35 & 10.40 & 29.71 \\
D13 & OGu & 11.20 & 373.30 & 33.33 & 0.89 & 25.20 & 28.31 \\
D14 & OGu & 7.70 & 279.90 & 36.35 & 1.26 & 31.00 & 24.60 \\
D24 & OGu & 19.10 & 819.70 & 42.92 & 1.98 & 54.2 & 27.37 \\
D26 & OGu & 17.50 & 206.10 & 11.78 & 0.53 & 13.5 & 25.47 \\
D32 & OGu & 14.60 & 166.70 & 11.42 & 0.62 & 17.8 & 28.71 \\
D33 & OGu & 4.30 & 120.60 & 28.05 & 0.51 & 12.6 & 24.71
\end{tabular}




\begin{tabular}{|c|c|c|c|c|c|c|c|}
\hline D34 & $\mathrm{OGu}$ & 3.20 & 211.90 & 66.22 & 0.71 & 20.5 & 28.87 \\
\hline D35 & $\mathrm{OGu}$ & 5.50 & 155.0 & 28.18 & 0.63 & 18.4 & 29.21 \\
\hline D36 & $\mathrm{OGu}$ & 4.10 & 395.90 & 96.56 & 0.91 & 25.4 & 27.91 \\
\hline D39 & $\mathrm{OGu}$ & 12.40 & 514.80 & 41.52 & 1.35 & 36.8 & 27.26 \\
\hline D40 & $\mathrm{OGu}$ & 8.50 & 300.50 & 35.35 & 1.29 & 34.3 & 26.59 \\
\hline Average & & 9.10 & 317.10 & 39.16 & 0.92 & 25.0 & 27.15 \\
\hline A15 & OGp & 8.70 & 371.20 & 42.67 & 0.60 & 18.00 & 30.0 \\
\hline B8 & OGp & 6.90 & 244.60 & 35.45 & 0.74 & 20.00 & 27.03 \\
\hline B9 & OGp & 8.60 & 336.80 & 39.16 & 0.66 & 18.20 & 27.58 \\
\hline B11 & OGp & 4.60 & 166.40 & 36.17 & 0.70 & 17.90 & 25.57 \\
\hline B16 & OGp & 9.60 & 343.80 & 35.81 & 0.95 & 23.00 & 24.21 \\
\hline B19 & OGp & 14.60 & 651.20 & 44.60 & 1.06 & 28.80 & 27.17 \\
\hline B20 & OGp & 23.40 & 1024.50 & 43.78 & 2.32 & 62.70 & 27.03 \\
\hline B23 & OGp & 7.90 & 298.60 & 37.80 & 0.64 & 19.50 & 30.47 \\
\hline D2 & OGp & 10.10 & 392.40 & 38.85 & 0.76 & 20.80 & 27.37 \\
\hline D11 & OGp & 14.10 & 554.90 & 39.35 & 1.63 & 42.90 & 26.32 \\
\hline D19 & OGp & 10.40 & 387.80 & 37.29 & 0.75 & 19.70 & 26.27 \\
\hline D25 & OGp & 17.50 & 798.70 & 45.64 & 1.81 & 47.80 & 26.41 \\
\hline Average & & 11.40 & 464.20 & 39.30 & 1.05 & 28.80 & 27.12 \\
\hline B10 & OGf & 14.40 & 619.10 & 42.99 & 1.61 & 43.00 & 26.71 \\
\hline A17 & OGf & 17.20 & 741.20 & 43.09 & 1.92 & 49.20 & 25.63 \\
\hline A10 & OGf & 8.10 & 353.80 & 43.68 & 0.87 & 22.10 & 25.40 \\
\hline Average & & 13.20 & 571.40 & 43.26 & 1.47 & 38.10 & 25.91 \\
\hline D28 & $\mathrm{CH}$ & 5.40 & 189.10 & 35.02 & 1.13 & 29.20 & 25.84 \\
\hline D29 & $\mathrm{CH}$ & 19.00 & 1159.70 & 61.04 & 1.43 & 36.10 & 25.24 \\
\hline D30 & $\mathrm{CH}$ & 26.30 & 629.60 & 23.94 & 0.8 & 22.00 & 27.50 \\
\hline Average & & 16.90 & 659.50 & 39.99 & 1.12 & 29.10 & 26.20 \\
\hline
\end{tabular}

TABLE 2. REE composition (ppm) of Idanre granite complex rocks

\begin{tabular}{lrrrrrrrr}
\hline & \multicolumn{2}{c}{ M } & \multicolumn{2}{c}{ OGu } & \multicolumn{2}{c}{ OGp } & \multicolumn{2}{c}{ OGf } \\
\hline REE & Mean & Range & Mean & Range & Mean & Range & Mean & Range \\
\hline $\mathrm{La}$ & 98.96 & $58-137.4$ & 118.46 & $55.2-332.9$ & 150.88 & $66.7-226.3$ & 215.3 & $141.7-344$ \\
$\mathrm{Ce}$ & 198.7 & $107.3-285.9$ & 217.46 & $111-627.5$ & 277.2 & $121.2-360.9$ & 395.7 & $281.8-622$ \\
$\mathrm{Pr}$ & 22.51 & $11.38-33.99$ & 21.52 & $10.55-59.2$ & 27.5 & $18.83-38.7$ & 54.8 & $29.88-76$ \\
$\mathrm{Nd}$ & 84.06 & $41.5-131.2$ & 70.96 & $36.5-182.6$ & 91.08 & $43.5-136.3$ & 126.9 & $88.5-187$ \\
$\mathrm{Sm}$ & 14.0 & $6.94-21.69$ & 10.31 & $5.76-18.94$ & 12.94 & $6.62-23.72$ & 18.06 & $12.29-25$ \\
$\mathrm{Eu}$ & 3.04 & $1.38-4.86$ & 1.92 & $1.36-2.67$ & 2.06 & $1.14-2.66$ & 2.47 & $2.28-2.74$ \\
$\mathrm{Gd}$ & 11.25 & $6.22-16.37$ & 7.68 & $3.79-14.45$ & 9.12 & $5.05-17.63$ & 12.7 & $8.52-17.1$ \\
$\mathrm{~Tb}$ & 1.54 & $0.91-2.07$ & 0.99 & $0.48-2.01$ & 1.17 & $0.66-2.46$ & 1.63 & $1.05-2.13$ \\
$\mathrm{Dy}$ & 8.5 & $5.35-11.25$ & 5.34 & $2.35-11.18$ & 6.11 & $3.90-12.91$ & 8.4 & $5.23-10.7$ \\
$\mathrm{Ho}$ & 1.60 & $1.09-1.92$ & 0.92 & $0.35-1.98$ & 1.05 & $0.6-2.32$ & 1.47 & $0.87-1-92$ \\
$\mathrm{Er}$ & 4.5 & $3.4-5.27$ & 2.57 & $0.91-3.67$ & 2.87 & $1.61-6.26$ & 3.97 & $2.44-5.08$ \\
$\mathrm{Tm}$ & 0.63 & $0.51-0.73$ & 0.35 & $0.17-0.77$ & 0.38 & $0.22-0.84$ & 0.50 & $0.29-0.64$ \\
$\mathrm{Yb}$ & 4.12 & $3.41-4.59$ & 2.17 & $0.83-4.67$ & 2.3 & $1.4-5.18$ & 3.14 & $1.92-4.04$ \\
$\mathrm{Lu}$ & 0.61 & $0.5-0.66$ & 0.31 & $0.17-0.66$ & 0.34 & $0.21-0.56$ & 0.45 & $0.26-0.56$ \\
$\mathrm{Ce} / \mathrm{Yb}$ & 46.82 & $29.32-64.95$ & 113.49 & $50.24-335.6$ & 134.97 & $58.57-211.1$ & 123.6 & $81.68-148$ \\
$\mathrm{SREE}$ & 454.01 & & 460.96 & & 585.0 & & 845.5 & \\
SLREE & 418.23 & & 438.71 & & 559.6 & & 810.8 & \\
SHREE & 35.78 & & 22.25 & & 25.4 & & 34.69 & \\
$\mathrm{LREE} / \mathrm{HREE}$ & 11.69 & & 19.72 & & 22.03 & & 23.37 & \\
\hline
\end{tabular}


TABLE 3. Abundance of REE and Zr, Hf, Y contents in geological materials (chondrite, crust, ultrabasic rocks, basalt, granite,

\begin{tabular}{lccccccc}
\hline Rare Earth Elements & Chondrite & Crust & Ultrabasic & Basalt & Granite & Greywacke & Shale \\
\hline $\mathrm{La}$ & 0.39 & 30 & 3.3 & 10.5 & 25 & & 20 \\
$\mathrm{Ce}$ & 1.05 & 60 & 8 & 35 & 46 & & 50 \\
$\mathrm{Pr}$ & 0.15 & 8.2 & 1.02 & 3.9 & 4.6 & & 6 \\
$\mathrm{Nd}$ & 0.62 & 28 & 3.4 & 17.8 & 18 & & 24 \\
$\mathrm{Sm}$ & 0.21 & 6 & 0.57 & 4.2 & 3 & & 6 \\
$\mathrm{Eu}$ & 0.072 & 1.2 & 0.16 & 1.27 & - & & 1 \\
$\mathrm{Gd}$ & 0.27 & 5.4 & 0.65 & 4.7 & 2 & & 6 \\
$\mathrm{~Tb}$ & 0.049 & 0.9 & 0.088 & 0.63 & 0.05 & & 1 \\
$\mathrm{Dy}$ & 0.32 & 3 & 0.59 & 3 & 0.5 & & 5 \\
$\mathrm{Ho}$ & 0.079 & 1.2 & 0.14 & 0.64 & 0.07 & & 1 \\
$\mathrm{Er}$ & 0.22 & 2.38 & 0.36 & 1.69 & 0.2 & & 2 \\
$\mathrm{Tm}$ & 0.037 & 0.48 & 0.053 & 0.21 & - & & 0.2 \\
$\mathrm{Yb}$ & 0.19 & 3 & 0.43 & 1.11 & 0.06 & & 3 \\
$\mathrm{Lu}$ & 0.03 & 0.5 & 0.064 & 0.2 & 1.01 & & 0.5 \\
$\mathrm{Trace}$ Elements & & & & & & & \\
$\mathrm{Zr}$ & 35 & 165 & 50 & 150 & 180 & 140 & 160 \\
$\mathrm{Hf}$ & 0.2 & 3 & 0.5 & 2 & 4 & 2 & 3 \\
$\mathrm{Y}$ & 2 & 30 & - & 25 & 40 & 10 & 25 \\
\hline
\end{tabular}
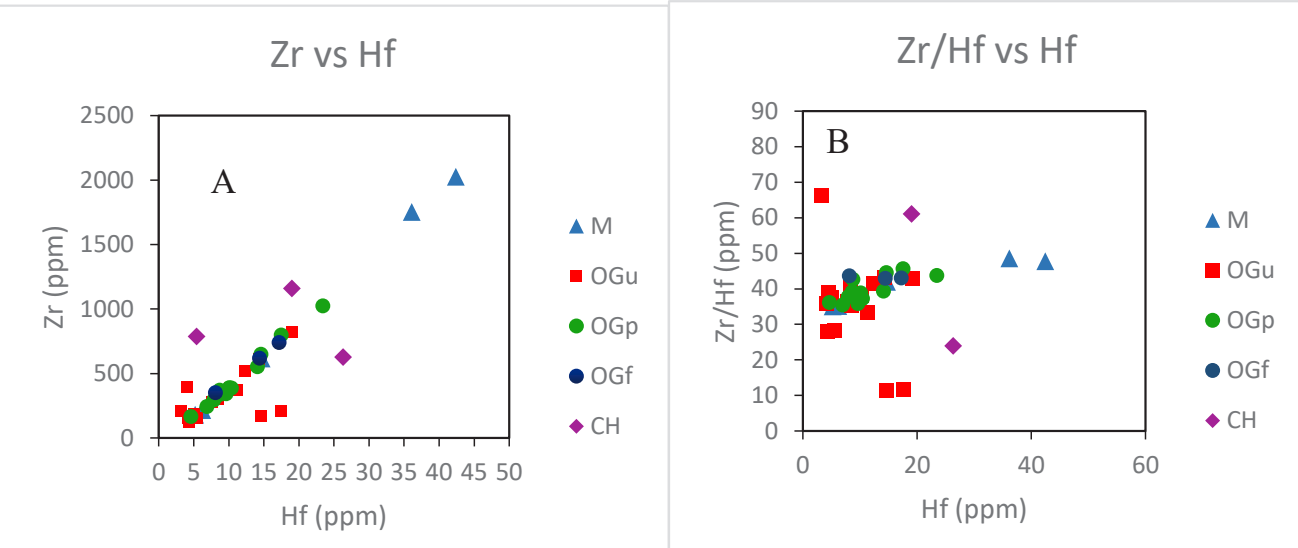

FIGURE 3. (A) $\mathrm{Zr}$ vs $\mathrm{Hf}$ (B): $\mathrm{Zr} / \mathrm{Hf}$ binary variation plots for Idanre Granite Complex
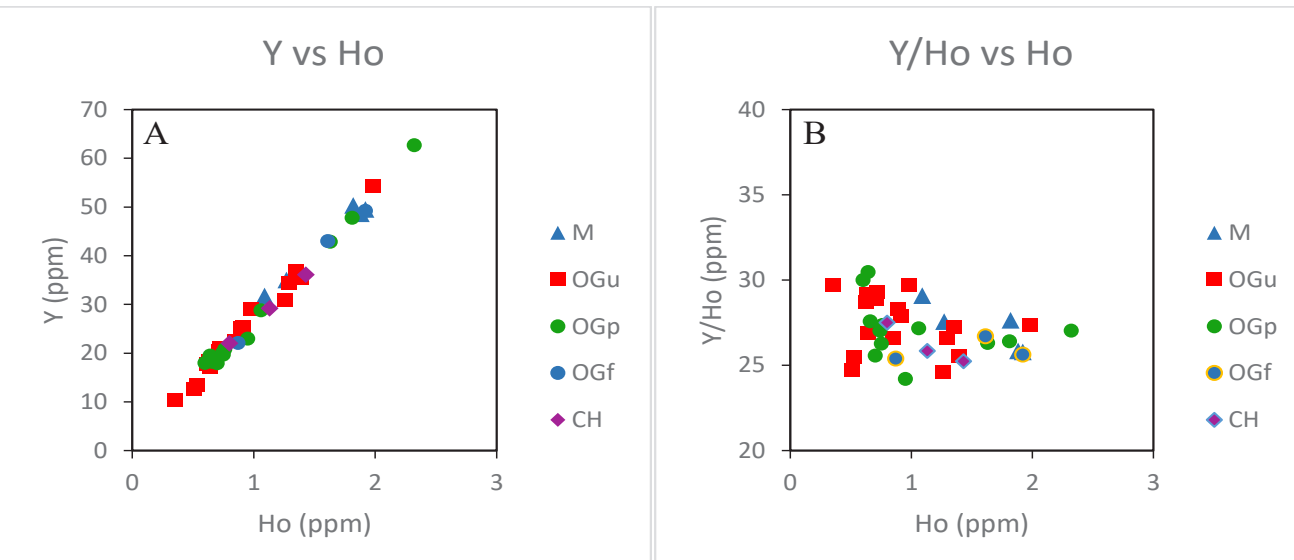

FIGURE 4. (A) Y vs Ho (B) Y/Ho vs Ho binary variation plots for the Idanre Granite Complex 
greywacke, and shale) after Taylor (1962) ZR-HF GEOCHEMISTRY OF IDANRE GRANITE

Migmatite in Idanre has $\mathrm{Y}$, Ho and $\mathrm{Y} / \mathrm{Ho}$ values which range between 31.7-50.3, 1.09-1.92, and 25.78-29-08 ppm, respectively. In the same order, the calculated means for these components are 43.0,1.60, and $27.18 \mathrm{ppm}$. The mean Yttrium content for coarse-grained granite $(\mathrm{OGu})$, porphyritic granite (OGp) and fine-grained granite are 25.0, 28.8, and $38.1 \mathrm{ppm}$, respectively. Similarly, mean Holmium content are (OGu) 0.92; (OGp) 1.05 and (OGf) $1.47 \mathrm{ppm}$. The mean Y/Ho value for the rocks are 27.15, 27.1, and 25.9. Like Zr-Hf pair, a trend exists in the abundances of these elements and their ratios for each group of rocks. The binary plot of Y vs Ho (Figure 4(a)) indicates a perfectly linear relationship between $\mathrm{Y}$ and Ho. In Y/Ho vs Ho binary plot (Figure 4(b)), most of the rocks instead of forming a straight-line trend clustered together between 0.5 and 2.0 on the Ho axis. However, the trend indicates that $\mathrm{Y}$ and Ho abundances and their ratio are much lower than $\mathrm{Zr}$ and $\mathrm{Hf}$ in all the rocks. It is also evident that Y-Ho content increases from OGu, OGp to a maximum in OGf. Conversely, the ratio $\mathrm{Y} / \mathrm{H}$ o reduces from coarse-grained granite, porphyritic granite while the least value was recorded for the fine-grained granite. Despite the slight variations, the mean $\mathrm{Y} / \mathrm{Ho}$ ratio is relatively close. The binary plots of Log $\mathrm{Zr} / \mathrm{Hf}$ vs Log Hf (Figure 5(a)) and Log Y/Ho vs Log Ho (Figure 5(b)) indicate that the rocks form a linear pattern on the $\mathrm{Log} \mathrm{Zr} / \mathrm{Hf}$ against Log Hf, whereas, the rocks show a very weak data spread but an aggregate of clustered points above 20 on Log Y/ Ho axis and around $1 \mathrm{ppm}$ on $\log$ Ho axis. The ratio $\mathrm{Y} /$ Ho for migmatite (27.1), coarse-grained granite (27.15), porphyritic granitoid (27.1) and fine-grained granitoid (25.9) clearly indicate that the rocks are all from same magma and the different units are comagmatic.

\section{Y-HO GEOCHEMISTRY OF IDANRE GRANITE}

Migmatite in Idanre has Y, Ho and Y/Ho values which range between 31.7-50.3, 1.09-1.92, and 25.78-29-08 ppm, respectively. In the same order, the calculated means for these components are 43.0, 1.60, and $27.18 \mathrm{ppm}$. The mean Yttrium content for coarse-grained granite $(\mathrm{OGu})$, porphyritic granite (OGp) and fine-grained granite are $25.0,28.8$, and $38.1 \mathrm{ppm}$, respectively. Similarly, mean Holmium content are (OGu) 0.92; (OGp) 1.05 and (OGf) $1.47 \mathrm{ppm}$. The mean $\mathrm{Y} / \mathrm{Ho}$ value for the rocks are 27.15, 27.1, and 25.9. Like Zr-Hf pair, a trend exists in the abundances of these elements and their ratios for each group of rocks. The binary plot of Y vs Ho (Figure 4(a)) indicates a perfectly linear relationship between $\mathrm{Y}$ and Ho. In Y/Ho vs Ho binary plot (Figure 4(b)), most of the rocks instead of forming a straight-line trend clustered together between 0.5 and 2.0 on the Ho axis. However, the trend indicates that $\mathrm{Y}$ and $\mathrm{Ho}$ abundances and their ratio are much lower than $\mathrm{Zr}$ and $\mathrm{Hf}$ in all the rocks. It is also evident that Y-Ho content increases from OGu, OGp to a maximum in OGf. Conversely, the ratio $\mathrm{Y} / \mathrm{Ho}$ reduces from coarse-grained granite, porphyritic granite while the least value was recorded for the fine-grained granite. Despite the slight variations, the mean Y/Ho ratio is relatively close. The binary plots of Log $\mathrm{Zr} / \mathrm{Hf}$ vs Log Hf (Figure 5(a)) and Log Y/Ho vs Log Ho (Figure 5(b)) indicate that the rocks form a linear pattern on the $\mathrm{Log} \mathrm{Zr} / \mathrm{Hf}$ against Log Hf, whereas, the rocks show a very weak data spread but an aggregate of clustered points above 20 on Log Y/ Ho axis and around $1 \mathrm{ppm}$ on Log Ho axis. The ratio Y/ Ho for migmatite (27.1), coarse-grained granite (27.15), porphyritic granitoid (27.1) and fine-grained granitoid (25.9) clearly indicate that the rocks are all from same magma and the different units are comagmatic.

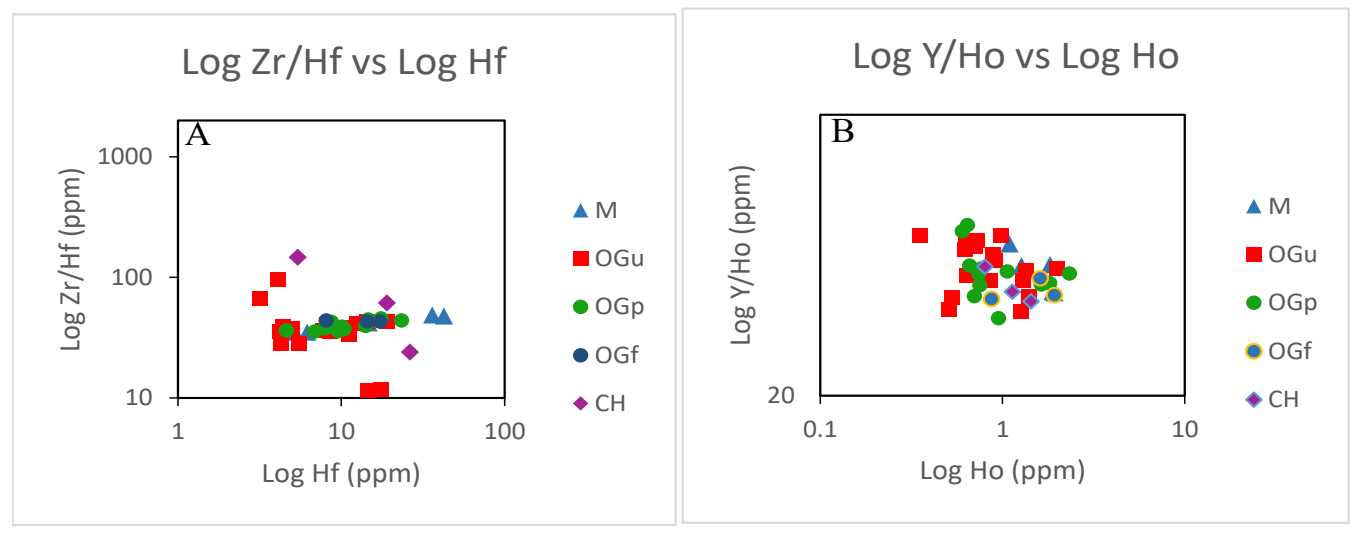

FIGURE 5. (A) $\log \mathrm{Zr} / \mathrm{Hf}$ vs $\log$ Hf. (B) $\log \mathrm{Y} / \mathrm{Ho}$ vs Log Ho for the Idanre Granite Complex 


\section{DISCUSSION}

\section{GEOCHEMISTRY OF ZR-HF AND Y-HO}

$\mathrm{Y}, \mathrm{Zr}$, and $\mathrm{Hf}$ are part of transition metals and have atomic numbers 39, 40, and 72 respectively, while Ho $(Z=67)$ belongs to the Lanthanoids group. Zirconium and hafnium are isomorphic elements that are readily accommodated in the crystal lattices of oxygen-bearing minerals or as substitutes for $\mathrm{Ta}, \mathrm{Nb}, \mathrm{Ti}, \mathrm{REE}, \mathrm{Ca}$, and Fe. As lithophile elements, they are common in several rock-forming minerals because of similarities between their ionic radii $\mathrm{Zr}^{4+}(0.79), \mathrm{Hf}^{4+}(0.78), \mathrm{Y}^{3+}(0.98), \mathrm{Ho}^{3+}(0.90), \mathrm{Ti}^{4+}$ (0.69); $\mathrm{Nb}^{5+}(0.72)$; $\mathrm{Ta}^{5+}(0.72)$. In effect, $\mathrm{Zr}$ distribution coefficients between equilibrium melts and crystals of major rock-forming minerals are relatively low but are still much higher for mafic minerals, such as biotite micas, amphiboles, and pyroxene, than for leucocratic minerals like feldspars and feldspathoids (Kogarko 2016). In natural environments such as rocks and soils, Y, and the REEs (Cerium and Europium not inclusive) occur solely in the trivalent oxidation state, both $\mathrm{Zr}$ and $\mathrm{Hf}$ are tetravalent. Similarity in mobility of $\mathrm{Zr}$ and $\mathrm{Hf}$ is attributed to comparable charge and ionic radius. In terrestrial materials, $\mathrm{Zr} / \mathrm{Hf}$ ratio is constraint within a narrow range, during crystallization of an ideal silicate melt, behavior of $\mathrm{Zr}$ and $\mathrm{Hf}$ is influenced by combination of ionic radius and electronic charge to produce $\mathrm{Zr} / \mathrm{Hf}$ ratios restricted to a very narrow limit within the crust (Zuddas et al. 2017).

Coherent elements pairs such as Zr-Hf, and of REEs group usually behave analogously in magmatic and some other natural processes. The fractionation of elements in pairs like $\mathrm{Zr}$-Hf, $\mathrm{Nb}$-Ta provides insight into physicochemical conditions under which these elements can be fractionated from each other, and hence, data on the fractionation of such analogously behaving elements are of paramount importance for evaluating such parameters of natural processes as oxygen fugacity, crystallization of mineral phases characterized by different distribution coefficients of coherent elements because of differences in the structures of these minerals, pressure, and temperature (Kogarko 2016). Related pairs (Zr-Hf), and (Y-Ho), and REE geochemical signatures could be useful to assess variations in mobility of HFSE and REE in anatectic melts, crystal fractionation, magmatic evolution and the determination of the degree of mineralization in granite suites (Jamali 2017). During partial melting processes, the elements $\mathrm{Zr}$ and $\mathrm{Hf}$ are incompatible, so low $\mathrm{Zr}$ and $\mathrm{Hf}$ values in magma or rock indicates low partial melting in the source; consequently, zircon, zirconolite and ilmenite either fractionated from melt or residual from source are the minerals that largely control $\mathrm{Zr}$, $\mathrm{Hf}$, and $\mathrm{Zr}$ / Hf abundances during magma differentiation or partial melting (Linnen et al. 2014). Melt water content have a major control over the behavior of Zirconium, Hafnium, and Heavy Rare Earth Elements, in fluid-dominated regimes, these elements are immobile, thus they are retained within solid phase throughout rock's anatexis (Richards 2005). The study of distribution of Y, REEs, $\mathrm{Zr}$ and $\mathrm{Hf}$ has been used as parameters controlling the behavior of trace elements having the same charge in a magmatic system. Many trace elements like $\mathrm{Zr}$, Hf, Y, $\mathrm{Ho}, \mathrm{Ta}$, and $\mathrm{Nb}$ occurring in geochemical systems are charge and radius-controlled, as such, the element pairs $\mathrm{Zr}-\mathrm{Hf}$ and Y-Ho will display similar behavior and maintain their individual chondritic ratio. In effect, the ratio $\mathrm{Y} /$ $\mathrm{Ho}, \mathrm{Zr} / \mathrm{Hf}$ offer copious evidence on the sources of $\mathrm{Y}$, $\mathrm{REE}, \mathrm{Zr}$, and $\mathrm{Hf}$ in the minerals or rock, and whether it has been produced from or changed by silicate melts (Bau 1996). The ratio Zr/Hf exhibited by most magmatic rocks approach chondritic values (35-40). However, when the ratio $\mathrm{Zr} / \mathrm{Hf}$ approaches $15-30$ in highly differentiated silica-rich rocks like granite, such may connote a direct relationship between $\mathrm{Zr}$ and Hf (Jamali 2017). The normalized chondrite REE plot (Figure 6) of the Idanre granite indicate they are characterized by high LREE/ HREE ratios but slightly low negative Eu anomaly. Trace elements diagram (Figure 7) showed Nb, P, Ti depletion.

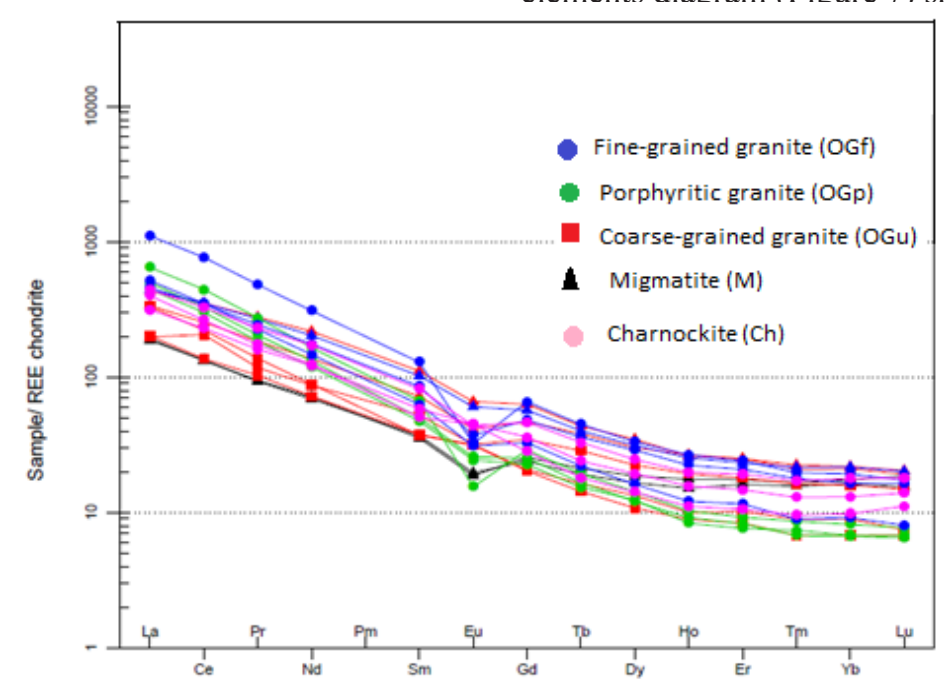

FIGURE 6. Chondrite normalized REE distribution pattern of the granitoids from Idanre Granite Complex 


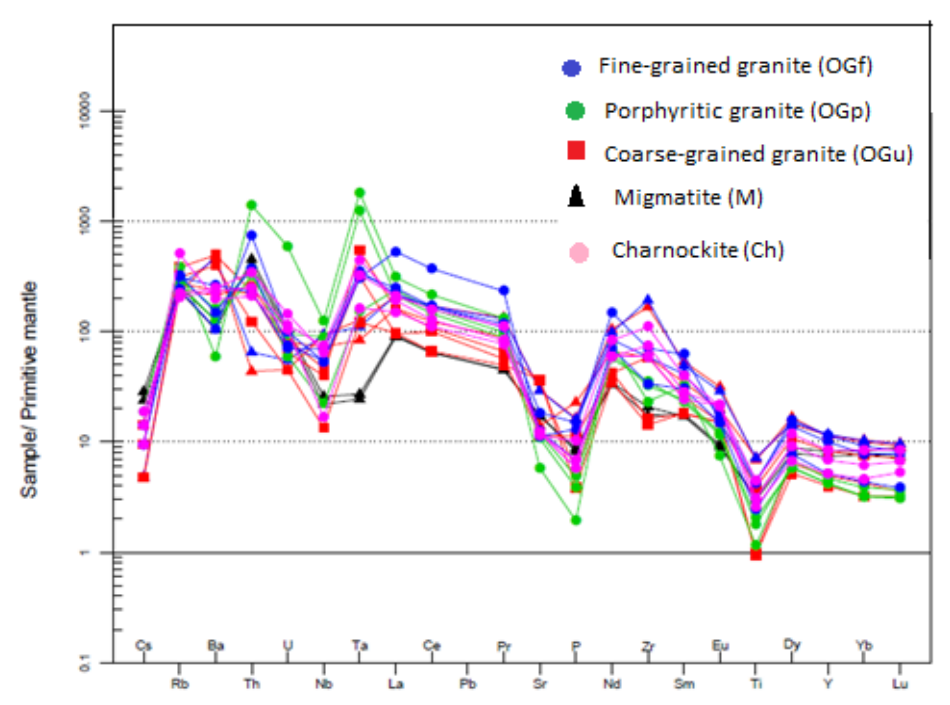

FIGURE 7. Spider diagram of trace and REE elements for the Idanre Granite Complex

\section{CONCLUSION}

The interrelated rare earth elements distribution pattern and close spatial association between migmatite and granitic series in the study area suggested a petrogenetic connection between the basement gneissic rocks and granitoids in Idanre area. The similarities between the mean values of the trace element pairs $\mathrm{Zr}$-Hf and Y-Ho for the different textural types of granites suggests they have comagmatic relationship. The dominance of LREE over HREE is an indication that the main minerals that play significant roles in the fractionation processes are those that favors LREE such as allanite while low contents of HREE likely indicate that zircon fractionation may be less significant. The closeness of $\mathrm{Zr} / \mathrm{Hf}$ ratios in the Idanre granite complex to the chondritic value (35-40), which falls outside the bracket for critically differentiated granitoids indicates the silicate melt that gave rise to the granite series are minimally differentiated. From the viewpoint that $\mathrm{Zr} / \mathrm{Hf}$ value of 23.3 or lower ratios are indicators of mineralized suites, the high mean $\mathrm{Zr} / \mathrm{Hf}$ ratio of Idanre granitoids (39.16, 39.29 and 43.26) likely indicate poor economic mineralization. The high values for the mean $\mathrm{Ce} /$ $\mathrm{Yb}$ ratios of the granite types indicate low partial melting in the source rocks. The magma that produced the Idanre granite complex had low water contents or low oxidation status due to the presence of hydrous mafic minerals (amphiboles) which is largely represented by hornblende.

\section{ACKNOWLEDGEMENTS}

The authors are thankful to the Management of the University of Malaya for providing the grant for geochemical analysis. His Royal Majesty, (Dr) Fredrick Adegunle Aroloye Gbolagunle Arubuefin IV JP, OFR, The Paramount ruler of Idanre Kingdom, the High Chiefs and the Idanre Tourist Officers are jointly appreciated for their cooperation to ensure successful and hitch-free geological mapping of the study area. Mr. Omagba David Ruke and all students who assisted during the fieldwork and sample haulage are acknowledged with thanks. The Department of Geology, University of Malaya who granted access to the laboratory equipment during samples preparation for analysis is hereby appreciated.

\section{REFERENCES}

Ajibade, A.C., Woakes, M. \& Rahaman, M.A. 1987. Proterozoic crustal development in the Pan-African regime of Nigeria. In Proterozoic Lithospheric Evolution, edited by Kroner, A. Washington DC: AGU. pp. 1-17.

Anifowose, A.Y.B. \& Kolawole, F. 2011. Talus Caves: Geotourist attractions formed by spheroidal and exfoliation weathering on Akure-Ado Inselbergs, Southwestern Nigeria. Ethiopian Journal of Environmental Studies and Management 4(3): 1-6.

Bau, M. 1996. Controls on the fractionation of isovalent trace elements in magmatic and aqueous systems: Evidence from 
$\mathrm{Y} / \mathrm{Ho}, \mathrm{Zr} / \mathrm{Hf}$ and Lanthanide tetrad effect. Contribution of Mineralogy and Petrology 123(3): 323-333.

Bea, F. 1996. Residence of REE, Y, Th and U in granites and crustal protoliths: Implications for the chemistry of crustal melts. Journal of Petrology 37(3): 521-552.

Clark, A.M. 1984. Mineralogy of the rare earth elements. In Rare Earth Geochemistry: Developments in Geochemistry 2, edited by Henderson, P. Amsterdam: Elsevier. pp. 33-61.

Dada, S.S. 2008. Proterozoic evolution of the NigeriaBoborema province. Geological Society of London Special Publication 294: 121-136.

Dalpé, C. \& Baker, D.R. 2000. Experimental investigation of large-ion-lithophile-element, high-field-strength-elementand rare-earth-element-partitioning between calcic amphibole and basaltic melt: The effects of pressure and oxygen fugacity. Contribution to Mineralogy and Petrology 140: 233-250.

Ekwueme, B.N. \& Kröner, A. 1992. Preliminary zircon evaporation ages from migmatitic gneisses in Kaduna, northern Nigeria: Evidence for an early Archaean (PreLeonian) event in the Nigerian basement complex. IGCP 280 International Conference. Salvador, Brazil.

Ferré, E.C., Deleris, J., Bouchez, J.L., Lar, A.U. \& Peucat, J.L. 1996. The Pan-African reactivation of Eburnean and Archaean provinces in Nigeria: Structural and isotopic data. Journal of the Geological Society of London 153(5): 719-728.

Ghani, A.A., Muzammil, S., Ng, T.F., Noer, E.H.I., Mohamad, T.M.Z., Nur, I., Quek, L.X., Ahmad, F.A.B., Meor, H.A.H., Jasmi, H.A.A. \& Amira, F.M. 2019. Ce Anomaly in I-type granitic soil from Kuantan, Peninsular Malaysia: Retention of zircon in the weathering product. Sains Malaysiana 48(2): 309-315.

Goodenough, K.M., Lusty, P.A.J., Roberts, N.M.W., Key, R.M. \& Garba, A. 2014. Post-collisional Pan-African granitoids and rare metal pegmatites in western Nigeria: Age, petrogenesis, and the 'pegmatite conundrum'. Lithos 200-201: 22-34.

Gromet, L.P. \& Silver, L.T. 1983. Rare earth element distributions among accessory minerals in a granodiorite and their petrogenetic implications. Geochimica et Cosmochimica Acta 47(5): 925-939.

Hoshino, M., Kimata, M., Shimizu, M., Nishida, N. \& Fujiwara, T. 2006. Allanite-(Ce) in granitic rocks from Japan: Genetic implications of patterns of REE and Mn enrichment. The Canadian Mineralogist 44(1): 45-62.

Jamali, H. 2017. The behavior of rare-earth elements, zirconium and hafnium during magma evolution and their application in determining mineralized magmatic suites in subduction zones: constraints from the Cenozoic belts of Iran. Ore Geology Reviews 81(Part 1): 270-279.

James, E., Ghani, A.A., Asis, J. \& Simon, N. 2019. Subduction roles for neogene volcanic rocks in Semporna Peninsula: Petrology and geochemistry perspective. Sains Malaysiana 48(11): 2473-2481.

Kogarko, L.N. 2016. Geochemistry of fractionation of coherent elements $(\mathrm{Zr}$ and $\mathrm{Hf}$ ) during the profound differentiation of peralkaline magmatic systems: A case study of Lovozero Complex. Geochemistry International 54(1): 1-6.

Linnen, R.L., Samson, I.M., Williams-Jonse, A.E. \& Chakhmouradian, A.R. 2014. Geochemistry of the rare-earth element, $\mathrm{Nb}, \mathrm{Ta}, \mathrm{Hf}$ and $\mathrm{Zr}$ deposits. Treatise on Geochemistry 13: $543-568$.

Nagasawa, H. 1970. Rare earth concentrations in zircons and apatites and their dacites and granites. Earth and Planetary Science Letters 9(4): 359-364.

Odeyemi, I.B. 1990. The petrology of a Pan-African pluton in Igarra, Southwestern Nigeria. Nigerian Journal of Science 24(1\&2): 181-193.

Ogunleye, P.O., Ike, E.C. \& Garba, I. 2005. Geochemical characteristics of the niobium-rich arfvedsonite granites, Younger Granites province of Nigeria. Chemie der Erde 65(3): 279-296.

Rahaman, M.A. 1988. Recent advances in the study of the basement complex of Nigeria. In $1^{\text {st }}$ Symposium on Pre-Cambrian Geology of Nigeria Proceeding. Special publication of Geological Survey of Nigeria 1: 11-41.

Richards, J.P. 2005. Cumulative factors in the generation of giant calc-alkaline porphyry Cu deposits. In Super Porphyry Copper and Gold Deposits: A Global Perspective, edited by Linden Park. South Australia: Porter Geoscience Consulting Publishing. pp. 259-274.

Taylor, S.R. 1962. Meteoritic and terrestrial rare earth abundance patterns. Geochimica et Cosmochimica Acta 26(1): 81-88.

Tobosun, I.A. 1981. Chronologie U/Pb evenements magmatiques du socle Precambrien du sudouest du Nigeria. PhD dissertation (Unpublished).

Umor, M.R., Ghani, A.A. \& Muda, N. 2019. Diversity of rocks in the stong complex based on field and petrographic studies. Sains Malaysiana 48(11): 2551-2563.

Zuddas, P., Ingualliato, C., Censi, P. \& Alessandro, W.D. 2017. $\mathrm{Zr}$-Hf fractionation during Water-Rock Interaction. 15th Water-Rock Interaction International Symposium, WRI-15, Procedia Earth and Planetary Science 17: 670-673.

Akinola O. Olagoke*, Azman A. Ghani \& Elvaene James Department of Geology

Faculty of Science

Ekiti State Universit

Ado-Ekiti

Nigeria

Akinola O. Olagoke*, Azman A. Ghani \& Elvaene James Department of Geology

Faculty of Science

Universiti Malaya

50603 Kuala Lumpur, Federal Territory

Malaysia

Elvaene James

Department of Geoscience

Faculty of Earth Science

Universiti Malaysia Kelantan

17600 Jeli, Kelantan Darul Ehsan

Malaysia

*Corresponding author; email: azmangeo@um.edu.my

Received: 4 November 2019

Accepted: 18 September 2020 